Article

\title{
The Possibilities of Gamifying the Mathematical Curriculum in the Early Childhood Education Stage
}

\author{
Verónica Marín-Díaz $^{1, *}{ }^{\circledR}$, Begoña E. Sampedro-Requena ${ }^{1}{ }^{\mathbb{D}}$, Juan M. Muñoz-Gonzalez ${ }^{1}$ \\ and Noelia N. Jiménez-Fanjul ${ }^{2}$ (D) \\ 1 Department of Education, Faculty of Education, University of Córdoba, 14004 Córdoba, Spain; \\ bsampedro@uco.es (B.E.S.-R.); juan.manuel@uco.es (J.M.M.-G.) \\ 2 Department of Mathematics, Faculty of Education, University of Córdoba, 14004 Córdoba, Spain; \\ noelia.jimenez@uco.es \\ * Correspondence: vmarin@uco.es; Tel.: +34-957-21-26-17
}

Received: 30 October 2020; Accepted: 11 December 2020; Published: 14 December 2020

\begin{abstract}
The addition of gamification to the classroom as a methodological tool means that the teacher's opinion about this has become an inflection point that can affect its use or not in the classroom. In this sense, the main objective of the present article is to explore the opinion of future Early Childhood education teachers on the use of this resource for the development of the mathematics curriculum at this education stage and to obtain an explanatory model that explains it. The design of the study utilized a descriptive perspective and a cross-sectional quantitative focus through a quantitative exploratory study. For data collection, an ad hoc questionnaire was utilized, which was administered to a sample of 232 teachers-in-training. The main result obtained was that the future early childhood education professionals considered that gamification could be a resource for the learning of specific mathematics contents, and this was shaped around a model of two elements. On one hand, the development of mathematical thinking, and on the other, the establishment of relationships between mathematical concepts. Lastly, we can conclude that elements such as age or gender do not determine the perception of the use of gamification in the early childhood education classroom.
\end{abstract}

Keywords: gamification; videogame; early childhood education; mathematics

\section{Introduction}

The diverse social, cultural and technological changes currently experienced by society, as indicated by [1], are shaping students and having an effect on their learning processes from different points of view. In this sense, games, in the broadest sense, have evolved as a methodological resource at the same time that society has moved forward. As of today, their use in a digital format has become very important, as the students in the classroom, from diverse educational stages, have been cataloged as technological youth, adolescents, and children. This is why the education community has begun to think of gamification as a valid strategy for the development of teaching-learning processes.

From the start, it must be indicated that current literature recognizes two ways of adding gamification to the classrooms, one supported by traditional games [such as Monopoly, Risk, cards, Parcheesi, the game of the goose, dungeon master, etc.], and the other supported by digital ones (Minecraft, Mario Bros, Fortnite, Pokemon Go, etc.) [2,3], with the objective of this article focusing on the latter trend.

The use of digital gamification or videogames, per se, to the learning process of the students, begins with the search for a transformation in education that promotes the growth of immersive learning of the students, and a demand for the improvement of the teachers' methodology. In addition, other researchers consider that the use of videogames will allow the students to be initiated in curricular 
competencies, which is the digital competence in this case [4-6], so that their learning process improves from another perspective.

At first, the digital gamification of the classrooms at any educational level implies accepting the use of digital games or videogames, a resource that has been demonized, hated, and loved by the education community and society at large [7-10]. It also implies that one must consider that the strategies utilized in gamification, such as the use of awards or badges, could be yet another element that motivates the students in their learning processes [3]. Thus, we must think beyond the thought that the final intent is to gamify the classroom. The use of gamification in the classroom, from a digital point of view, implies the use of videogames or strategies such as Escape Room or educational Breakouts to a level where the main objective is to introduce the curricular contents in a manner that is attractive to the student $[1,3]$. Thus, the contents that are considered to be difficult, either due to their nature, the manner of teaching them, or the manner of learning them, could be presented in a more motivational way, with their virtues shown to the students [11]. This will get the student's attention and promote internal strategies of assimilation and comprehension of this content.

In this sense, various successful experiments on the use of videogames in the classrooms exist, as a tool for propitiating effective learning, and at the same time, for favoring the cohesion and integration of the content to the social reality of the student. Authors such as $[12,13]$ have pointed out that the gamified classroom promotes improvements in learning, metacognition, evaluation, and the process of conceptual support of the students. Along this line, [14] conducted a study with teachers from the area of special education and concluded that when they implemented gamification strategies into their classes, an improvement was achieved in the reasoning processes of the students. As a result, we could say that gamification, per se, tries to promote motivation for the content and the creativity of the individuals. On the other hand, it is interesting to note how the studies that have focused their attention on gender have underlined the importance of their use to foment the mathematical talents of girls [15].

Focusing our attention on the area of mathematics, we find the work by [4], who underlines how a game created more than two decades ago, The Lemmings, helps with the initiation of the basic contents of mathematics, just as the data presented by [11], who, after using various digital games, verified that significant learning of algebra content was achieved. On their part, [16] conducted a pretest-posttest study utilizing $Q R$ codes placed on cards, which allowed the students to perform different mathematics activities. The main result was that an improvement was observed in the acquisition of the rational number concept, improving the connections between its different representations such as fractions, decimals, and percentages. Along this line, [17], utilizing experimental and control groups, concluded that significant improvements had been achieved on the comprehension of basic concepts of mathematical logic of the students with whom digital games had been used as a digital resource, as compared to those who had followed a traditional methodology of learning. These results [18] show that the use of game-based interactive materials in the mathematics classroom promotes the improvement of the comprehension of mathematical concepts of the students. Therefore, the use of digital resources [19], defined as manipulative materials that allow us to visualize mathematical concepts more easily and in a more attractive manner, signifies a helping tool in the process of abstraction of mathematical concepts when coming into existence as virtual models of mathematical concepts [20].

Focusing our interest on the early childhood stage, it should first be indicated that this stage is characterized by being a point in time in which immersion into the curricular contents begins, which will be further developed in higher education stages. It is in this initial stage when the teachers begin to observe the first differences in the act of teaching and learning, meaning that different levels of learning and understanding of the contents taught to begin to appear [12,21,22]. As indicated by [23], learning is conducted due to curiosity, exploration, and immersion into the content; experimentation occurs, and initiation into research begins in a playful manner, as games are the main elements in learning processes [24]. For this reason, we can consider that gamification in the early childhood classroom 
will provide a new learning scenario where fiction comes closer to the educational reality of the student, thereby promoting a creative learning process, which is vital in the first years of socialization of individuals. As for the area of mathematics, we are in agreement with [24] in that the process of logic-mathematics acquisition is conducted through a reflective process that is never forgotten so that the use of different types of resources could promote this reflection in a more effective manner.

Diverse research studies $[4,25,26]$ have pointed out that the use of gamification for teaching the curricular content in the area of mathematics in the early childhood stage promotes experiencing the content, which results in a positive view of the students towards this subject matter. We are in agreement with $[27,28]$ that the use of digital games in the area of mathematics implies that the student learns, in a playful manner, concepts such as probability while they play, so that learning is produced in a manner that is more motivating and personal to the student, helping with the overcoming of obstacles during this learning process.

The objectives of the present research study are:

- To determine the perceptions of the teachers-in-training about the question of if the use of videogames allows for the development of the curriculum in the early childhood stage in the area of mathematics;

- To explore the existence of different dimensions about the use of videogames, to make progress feasible in the curriculum of the early childhood stage, in the area of mathematics;

- To learn about the behavior of these factors, considering their relationships and the existence of an explanatory model for them.

The following hypothesis has been posited with the objectives described above:

Starting hypothesis: There are significant differences in mathematical thinking, depending on the establishment of relationships between concepts, without it being influenced by the age and gender of the study subjects.

\section{Materials and Methods}

The research study utilized a descriptive design and a cross-sectional quantitative focus, given that a survey was utilized as the data collection instrument.

\subsection{Sample}

The sample was selected by utilizing a nonprobabilistic, convenience sampling method [29], given that sample was accessed through the classroom where the virtual teaching was done.

The sample was composed of 232 students enrolled in the early childhood education degree at the University of Cordoba (Spain). If the sampling error calculation for finite populations is lower than $3 \%$, as in our case, it is understood that the sample is significant, considering what is mentioned in [30]. In the sample, we found that $88.8 \%$ were women, $10.8 \%$ men, and $0.4 \%$ identified themselves as transgender. From the start, it can be indicated that there was a bias towards the female gender. Nevertheless, it should be pointed out that as indicated by [31,32], this university degree tends to have a higher female component than other university studies, just as with engineering degrees, where the presence of men tends to be higher [32]. As for the academic year, 50.4\% were in their first year, and $49.6 \%$ in their second year. The mean age of the participants was 19.69 years old (SD $=2.408)$, which was distributed, as shown in Table 1.

Focusing our attention on the devices they possessed, and which could be used to play, we found that $24.1 \%$ had a laptop and a smartphone, while only $0.4 \%$ had a smartphone + videogame console or a laptop + smartphone, or a desktop + tablet + smartphone. It is interesting to note that $11.2 \%$ had access to all the devices shown (laptop, desktop, smartphone, videogame console, and tablet) (see Table 2). 
Table 1. Distribution of the sample according to age.

\begin{tabular}{|c|c|c|c|c|c|c|}
\hline & & \multicolumn{5}{|c|}{ Gender } \\
\hline & & Age $^{1}$ & Men & Women & Transgender & N. \\
\hline \multirow{22}{*}{ Academic year } & \multirow{10}{*}{ First year } & 17 & 0 & 14 & 0 & 14 \\
\hline & & 18 & 7 & 38 & 1 & 46 \\
\hline & & 19 & 5 & 16 & 0 & 21 \\
\hline & & 20 & 3 & 15 & 0 & 18 \\
\hline & & 21 & 1 & 6 & 0 & 7 \\
\hline & & 22 & 2 & 4 & 0 & 6 \\
\hline & & 23 & 0 & 2 & 0 & 2 \\
\hline & & 24 & 0 & 2 & 0 & 2 \\
\hline & & 38 & 0 & 1 & 0 & 1 \\
\hline & & Total & 18 & 98 & 1 & 117 \\
\hline & \multirow{12}{*}{ Second year } & 18 & 0 & 16 & 0 & 16 \\
\hline & & 19 & 1 & 41 & 0 & 42 \\
\hline & & 20 & 1 & 15 & 0 & 16 \\
\hline & & 21 & 2 & 14 & 0 & 16 \\
\hline & & 22 & 1 & 11 & 0 & 12 \\
\hline & & 23 & 0 & 4 & 0 & 4 \\
\hline & & 24 & 1 & 3 & 0 & 4 \\
\hline & & 25 & 1 & 0 & 0 & 1 \\
\hline & & 26 & 0 & 1 & 0 & 1 \\
\hline & & 27 & 0 & 2 & 0 & 2 \\
\hline & & 34 & 0 & 1 & 0 & 1 \\
\hline & & Total & 7 & 108 & 0 & 115 \\
\hline
\end{tabular}

${ }^{1} \mathrm{~N}$ total $=232$

Table 2. Digital devices available for playing.

\begin{tabular}{ccc}
\hline Digital Devices Available for Playing & f. ${ }^{\mathbf{1}}$ & $\mathbf{\%}$ \\
\hline Laptop computer & 18 & 7.8 \\
Smartphone & 10 & 4.3 \\
Laptop computer + tablet + smartphone & 34 & 14.7 \\
All the devices & 27 & 11.6 \\
Laptop computer + tablet + smartphone + videogame console & 26 & 11.2 \\
Laptop computer + smartphone + videogame console & 29 & 12.5 \\
Laptop computer + smartphone & 56 & 24.1 \\
Laptop computer + desktop computer + smartphone + videogame console & 4 & 1.7 \\
Laptop computer + desktop computer +tablet + smartphone & 9 & 3.9 \\
Laptop computer + tablet+ smartphone & 2 & 0.9 \\
Laptop computer + desktop computer + smartphone & 6 & 2.6 \\
tablet + smartphone & 4 & 1.7 \\
Smartphone + videogame console & 1 & 0.4 \\
Laptop computer + smartphone & 1 & 0.4 \\
Laptop computer + tablet & 4 & 1.7 \\
Desktop computer + tablet + smartphone & 1 & 0.4 \\
\hline$\quad{ }^{1}$ N 232 f frequen
\end{tabular}

${ }^{1} \mathrm{~N}=232 ; \mathrm{f}$. = frequency.

As for their characterization as videogame players, in our sample, $44 \%$ occasionally played, $24.1 \%$ sometimes, and 4.3 and $1.3 \%$ often or very much, respectively. It is notable that $26.3 \%$ indicated that they had never played. As a function of these results, and when asked about the number of hours they played, we found that $88.4 \%$ and $90.5 \%$ played between 1 and $3 \mathrm{~h}$ throughout the week and throughout the weekend, respectively. It is interesting that $0.9 \%$ played less than $10 \mathrm{~h}$ during the week, and $1.3 \%$ during the weekend (see Figure 1).

Lastly, when asked about the type of videogames they tended to use, $72.8 \%$ utilized the one from the videogame platforms, $23.3 \%$ fighting games, and 3.9\% strategy games. 


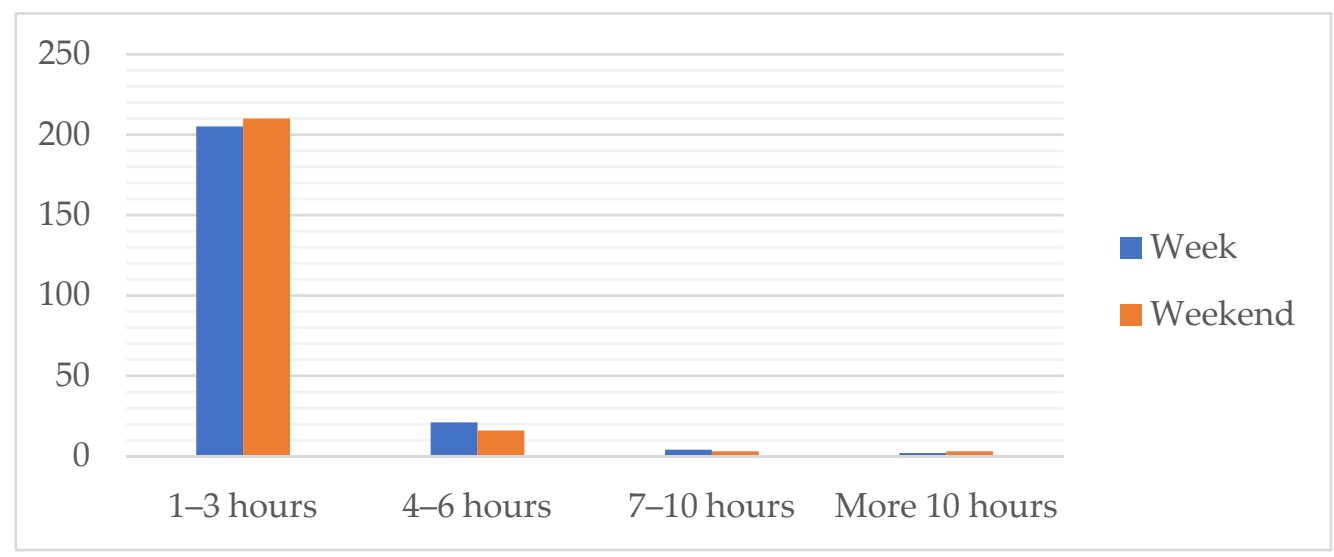

Figure 1. Distribution of the hours of play during the week and the weekend.

\subsection{Instrument}

The instrument utilized for the collection of data was the survey created ad hoc under the parameters found in [33], which sets the minimum education levels in Early Childhood Education in Spain, summarized in [34], which regulates the curriculum of Early Childhood Education in Andalusia. This instrument was composed of 2 dimensions comprised of 25 items, written in an affirmative, closed and polythematic character. This was an anonymous questionnaire, which was administered online without the in situ assistance of the researcher. A Likert-type response scale was utilized, composed of five response options (where 1 indicated complete disagreement and 5 complete agreement). This type of response scale with this number of options will allow for coming close to the assumption of continuity. In addition, the instrument contained a set of independent variables which allowed us to describe the participating sample: gender, age, academic year, digital devices available for playing (laptop computer, desktop computer, Tablet, Smartphone, and Videogame console), hours spent playing during the week and the weekend, and type of games they like to play.

To determine the validity of the instrument created, an exploratory factor analysis (EFA) was performed through the use of polychoric matrices, along with an "optimal implementation of parallel analysis" [35] and "non-weighted least squares" with a "weighted Oblimin rotation" [36] to determine the number of factors, utilizing the statistical package SPSS 23 and the Factory Analysis (10.10.03) software. This analysis allowed for the verification of the viability of the construct through the correlation matrix 0.000; Bartlett's sphericity test, with a significance of 0.000 ; and $\mathrm{KMO}=0.931$, as well as the root mean square of residuals (RMSR) $=0.038$, with extracted factors that explained $63.27 \%$ of the variance, and whose rotated factors had loads higher than 0.3 , providing us with the following two-factor structure (see Table 3).

Therefore, through the EFA, a structure of the instrument was obtained, shaped by two factors, which are:

- Development of mathematical thinking: this dimension encompasses a set of items that refer to the videogame as a facilitator for the development of mathematical thinking of the students through the acquisition of notions such as quantity, order, magnitudes or measurements, among others; as well as the representation and interpretation of reality through mathematical elements;

- Establishment of relationships between concepts: this dimension spans a series of items that allude to the ability of videogames to facilitate the creation of relationships between the qualitative and quantitative mathematical concepts, as well as to collect and represent data and information.

In addition, a confirmatory factorial analysis (CFA) was performed, which allowed us to compare the fit indices of the model obtained in the EFA, taking into account the following tests: $\chi 2$ test/degrees of freedom, comparative fit index (CFI), incremental fit index (IFI), normed fit index (NFI), the Tucker-Lewis index (TLI), the root mean square error of approximation (RMSEA), and the expected cross-validation index (ECVI). In the first analysis, the results found indicated that items 2, 3, 6, and 14 from the 
first dimension should be eliminated, as well as items 18 and 25 from the second dimension, as the modification indices indicated the existence of covariances between the errors associated with the items that belonged to different factors. Once the model was reformulated, with a total of 19 items, the following results were obtained: $\mathrm{x}^{2}=171.97 ; \mathrm{df}=131 ; p=0.009 ; \mathrm{X}^{2} / \mathrm{df}=1.31 ; \mathrm{CFI}=0.975 ; \mathrm{IFI}=0.976$; $\mathrm{NFI}=0.905 ; \mathrm{TLI}=0.967$; RMSEA $=0.053$; and ECVI $=2.63$. Taking into account the values found, adequate results were observed in that model, as a value lower than 0.060 was found for RMSEA, with values higher than 0.90 in CFI, IFI, NFI and NNFI $[37,38]$.

Table 3. Matrix of rotated factors.

\begin{tabular}{ccc}
\hline Variables & Factor 1 & Factor 2 \\
\hline V 1 & 0.632 & \\
V 2 & 0.615 & \\
V 3 & 0.631 & \\
V 4 & 0.729 & \\
V 5 & 0.630 & \\
V 6 & 0.419 & \\
V 7 & 0.384 & \\
V 8 & 0.709 & \\
V 9 & 0.772 & \\
V 10 & 0.761 & \\
V 11 & 0.600 & \\
V 12 & 0.635 & \\
V 13 & 0.396 & \\
V 14 & 0.303 & \\
V 15 & & 0.568 \\
V 16 & & 0.326 \\
V 17 & & 0.569 \\
V 18 & & 0.543 \\
V 19 & & 0.443 \\
V 20 & & 0.390 \\
V 21 & & 0.387 \\
V 22 & & 0.545 \\
V 23 & & 0.893 \\
V 24 & & 0.828 \\
V 25 & & 0.499 \\
\hline
\end{tabular}

On the other hand, and to verify if the reliability of the instrument was appropriate, Cronbach's alpha was calculated to study the internal consistency, with a value of $\alpha=0.962$ obtained for the instrument as a whole and values of $\alpha=0.962$ for factor 1 , and $\alpha=0.932$ for factor 2 , indicating high-reliability values [39].

Lastly, alluding to the data collection procedure, it should be noted that $15 \mathrm{~min}$ were provided for completing the questionnaire, with the study researchers present through a videoconference call to resolve any possible doubts that could arise during this process.

\subsection{Analysis Performed}

Once the collection of data were complete, the following statistical analyses were performed to provide an answer to the objectives set in this study:

- A descriptive study of the two dimensions addressed in the questionnaire through the measurements of central tendency (mean) and dispersion (standard deviation).

- A correlational study between the two dimensions of the instrument through bivariate correlations.

- ANOVA, ANCOVA and a regression study to establish the explanatory model of dimension 1 as a function of the values from dimension 2 through linear regressions. 


\section{Results}

\subsection{Descriptive Study}

In the first place, the results (mean, standard deviation, kurtosis, and asymmetry) of the descriptive study are shown, which was conducted with the final version of the instrument, composed of 19 items (see Appendix A, Table A1).

As observed in Appendix A (Table A1), only the items that referred to reader comprehension (items 2 and 3) were evaluated low by the teachers-in-training, with the rest accepted indifferently, in disagreement with the findings from [12], highlighting those that referred to the help provided by this resource to the early childhood students, for the establishment of relationships between different matters and sizes (items 16 and 17).

As for the dimensions established by the CFA, it was verified that the descriptive values showed high values for the mean, as shown in Table 4, with the results being:

Table 4. Descriptive study of the dimensions.

\begin{tabular}{ccccccc}
\hline Factors & M. & SD & \multicolumn{2}{c}{ Asymmetry } & \multicolumn{2}{c}{ Kurtosis } \\
\hline Development of mathematical thinking (factor 1) & 3.87 & 0.741 & -0.747 & 0.160 & 1.147 & 0.318 \\
Establishment of relationships between concepts (factor 2) & 3.95 & 0.719 & -0.769 & 0.160 & 1.494 & 0.318 \\
\hline
\end{tabular}

\subsection{Inferential Study}

After a Student's $t$-test was performed according to gender, and with the objective of verifying if hypothesis 1 is accepted or not, the results showed that no significant differences were found. Therefore, it can be inferred that the gender variable did not determine the use of the videogames as a curricular tool in the early childhood education stage.

With respect to the starting hypothesis, an analysis of variance (ANOVA) and an analysis of covariance (ANCOVA) were performed, which did not show differences when using either age or gender as the discriminatory variable. Thus, the hypothesis set forth must be rejected, and it must therefore be pointed out that age was not a determining variable between mathematical thinking and the use of video games as a resource in the early childhood classroom.

\subsection{Correlational Study}

The correlational study performed referred to Pearson's correlation test for bivariate relations between the factors. As observed, the relation between the dimensions is positive. As one increases, so do the other by a high [39] and a significant amount $(\mathrm{r}=0.710$ and $p<0.001)$.

\subsection{Regression Analysis}

In the search for an explanatory model that possesses the best parsimony possible, the multivariate analysis of linear regressions shows that factor 1 (development of mathematical thinking) can be explained by factor 2 (establishment of relationships between concepts) and gender and age. This analysis obtained the following parameters: $F(1,230)=337.63$ and $p<0.001$; with a corrected coefficient of determination $\mathrm{R}^{2}=0.593$, and a Durbin-Watson value $=1.9$, which indicates the interdependence of the residues [40]. The only variable that intervenes in the Factor 2 equation has the following statistical values: $\mathrm{t}=18.37$ and $p<0.001$.

Analyzing what is shown in Table 5, the equation explains the development of mathematical thinking, factor $1=0.59+0.81$ factor 2 , with a root mean square error of 0.22 . Likewise, to generalize the explanatory model, the residues were studied, observing the non-multicollinearity with the VIF value $=1.000$, and the independence of the residues. On the other hand, their linearity and the homoscedasticity of the residues, observed in figures, comply with these assumptions [41] just as their values of normality through the Kolmogorov-Smirnov test $(Z=0.078$ and $p=0.200)$. 
Table 5. Linear regression of the development of mathematical thinking ${ }^{a}$ in early childhood education with the use of video games.

\begin{tabular}{|c|c|c|c|c|c|c|c|c|c|}
\hline Variables & B & E.S. & Beta & $\mathbf{t}$ & Sig. & Zero Order & Partial R & $\begin{array}{c}\text { Semi- } \\
\text { Partial R }\end{array}$ & Tolerance VIF \\
\hline Constant ${ }^{b}$ & 0.587 & 0.180 & & 3.257 & $0.001 *$ & & & & \\
\hline Factor $2^{b}$ & 0.813 & 0.044 & 0.771 & 18.375 & $0.000 *$ & 0.771 & 0.771 & 0.771 & 1.000 \\
\hline
\end{tabular}

Note. ${ }^{\text {a }}$. Dependent variable: development of mathematical thinking. ${ }^{\mathrm{b}}$. Predictors: (constant) factor 2 (establishment of relationships between concepts). ${ }^{*}$ Level of significance, $p=0.05$.

Given the complexity of the relation between the dependent variable (F1) and the independent variable (F2), an analysis of covariance (ANCOVA) was performed. Initially, an ANOVA was performed through a univariate linear model with a full factorial design between the main effect F2 and the interaction between F1 and F2, whose results are shown in Table 6.

Table 6. Tests of the inter-subject effects between F1 and F2.

\begin{tabular}{ccccccc}
\hline Origin & Sum of Squares Type II & G1 & Quadratic Mean & F & Sig. $^{*}$ & Partial Eta-Squared \\
\hline Corrected model & $77.419^{a}$ & 4 & 19.355 & 87.346 & 0.000 & 0.606 \\
\hline Intersection & 3437.280 & 1 & 3437.280 & $15,512.005$ & 0.000 & 0.986 \\
\hline F2 & 77.419 & 4 & 19.355 & 87.346 & 0.000 & 0.606 \\
\hline Error & 50.301 & 227 & 0.222 & & & \\
\hline Total & 3565.000 & 232 & & & & \\
\hline Total corrected & 127.720 & 231 & & & & \\
\hline
\end{tabular}

Note. ${ }^{\text {a }}$. R-squared 0.606 (R-squared corrected $\left.=0.599\right)$. Dependent variable F1 ${ }^{*}$. Level of significance $p=0.05$.

Utilizing the development of mathematical thinking (F1) as the dependent variable and the establishment of relationships between concepts (F2) as the independent one, it can be observed that the main effect $\mathrm{F}(4227)=87.346$ and $p<0.005$, as well as the interaction, are significant.

Afterward, the univariate linear model was repeated, with the ANCOVA performed with the covariables gender and age, utilizing the development of mathematical thinking (F1) as the dependent variable and the establishment of relationships between concepts (F2) as the independent one. The results obtained are shown in Table 7.

Table 7. Tests of the inter-subject effects between F1 and F2 with covariables gender and age.

\begin{tabular}{|c|c|c|c|c|c|c|}
\hline Origin & Sum of Squares Type II & G1 & Quadratic Mean & $\mathbf{F}$ & Sig. & Partial Eta-Squared \\
\hline Corrected model & $78.871^{\mathrm{a}}$ & 13 & 6.067 & 27.075 & 0.000 & 0.618 \\
\hline Intersection & 0.432 & 1 & 0.432 & 1.929 & 0.166 & 0.009 \\
\hline $\mathrm{F} 2$ & 0.124 & 1 & 0.124 & 0.555 & 0.457 & 0.003 \\
\hline Gender & 0.025 & 1 & 0.025 & 0.111 & 0.739 & 0.001 \\
\hline Age & 0.104 & 1 & 0.104 & 0.463 & 0.497 & 0.002 \\
\hline $\mathrm{F} 2 *$ Gender & 0.154 & 1 & 0.154 & 0.688 & 0.408 & 0.003 \\
\hline $\mathrm{F} 2 *$ Age & 0.132 & 1 & 0.132 & 0.588 & 0.444 & 0.003 \\
\hline $\mathrm{F} 2 *$ Gender $*$ Age & 0.186 & 2 & 0.093 & 0.416 & 0.660 & 0.004 \\
\hline Error & 48.849 & 218 & 0.224 & & & \\
\hline Total & 3565.000 & 232 & & & & \\
\hline Total corrected & 127.720 & 231 & & & & \\
\hline
\end{tabular}

Note. $^{\text {a } . ~ R-s q u a r e d ~} 0.618$ (R-squared corrected $\left.=0.595\right)$. Dependent variable F1 ${ }^{*}$. Level of significance $p=0.05$. 
In light of the data comparisons shown in Tables 6 and 7, it can be concluded that the effect between the dependent variable F1 and the independent variable F2 is altered by the covariables, given that significance does not exist in the model. Thus, the results indicate that a study must be made with the covariables separately to verify if any of the covariables has an influence on the dependent variable, with the results shown in Tables 8 and 9.

Table 8. Tests of the inter-subject effects between F1 and F2 with covariable gender.

\begin{tabular}{ccccccc}
\hline Origin & Sum of Squares Type II & G1 & Quadratic Mean & F & Sig. & Partial Eta-Squared \\
\hline Corrected model & $77.906^{\text {a }}$ & 7 & 11.129 & 50.046 & 0.000 & 0.610 \\
\hline Intersection & 111.282 & 1 & 111.282 & 500.406 & 0.000 & 0.691 \\
\hline F2 & 0.374 & 2 & 0.187 & 0.840 & 0.433 & 0.007 \\
\hline Gender & 0.343 & 1 & 0.343 & 1.540 & 0.216 & 0.007 \\
\hline F2 * Gender & 0.144 & 2 & 0.072 & 0.324 & 0.724 & 0.003 \\
\hline Error & 49.814 & 224 & 0.222 & & & \\
\hline Total & 3565.000 & 232 & & & & \\
\hline Total corrected & 127.720 & 231 & & & & \\
\hline Note. ${ }^{\text {a }}$ R-squared 0.610 (R-squared corrected $\left.=0.598\right)$. Dependent variable F1 *. Level of significance $p=0.05$.
\end{tabular}

Table 9. Tests of the inter-subject effects between F1 and F2 with covariable age.

\begin{tabular}{ccccccc}
\hline Origin & Sum of Squares Type II & G1 & Quadratic Mean & F & Sig. & Partial Eta-Squared \\
\hline Corrected model & $78.211^{\text {a }}$ & 8 & 9.776 & 44.035 & 0.000 & 0.612 \\
\hline Intersection & 45.692 & 1 & 45.692 & 205.806 & 0.000 & 0.480 \\
\hline F2 & 0.771 & 3 & 0.257 & 1.157 & 0.327 & 0.015 \\
\hline Age & 0.377 & 1 & 0.377 & 1.700 & 0.194 & 0.008 \\
\hline F2 * Age & 0.414 & 3 & 0.138 & 0.622 & 0.602 & 0.008 \\
\hline Error & 49.509 & 223 & 0.222 & & & \\
\hline Total & 3565.000 & 232 & & & & \\
\hline Total corrected & 127.720 & 231 & & & & \\
\hline
\end{tabular}

Note. ${ }^{\text {a }}$. R-squared 0.612 (R-squared corrected $=0.598$ ). Dependent variable F1 *. Level of significance $p=0.05$.

Tables 8 and 9 show that none of the covariables has an influence on the dependent variable of the univariate linear model. In summary, the results show that factor 1 (development of mathematical thinking) can be explained by factor 2 (establishment of relationships between concepts), without gender or age having an influence.

On the other hand, the participating sample was divided as a function of the student's gender, for a more itemized study of the development of mathematical thinking in the use of the video games, obtaining a variation in this variable as a percentage which is explained with factor 2.

In the case of the men, the general model only explained $17.5 \%\left(\mathrm{R}^{2}=0.175\right)$, with the parameters being $\mathrm{F}(1,23)=6.092$ and $p=0.021$; factor 2 , which is the only variable that intervenes in the equation, obtained the following statistics: $\mathrm{t}=2.46$ and $p=0.021$. After analyzing Table 10 , the equation that explains the development of mathematical thinking for the men is factor $1=1.63+0.60$ factor 2 , with a root mean square error of 0.27 . 
Table 10. Linear regression of the development of mathematical thinking ${ }^{a, c}$ in early childhood education for men.

\begin{tabular}{|c|c|c|c|c|c|c|c|c|c|c|}
\hline Variables & B & E.S. & Beta & $t$ & Sig. * & Zero Order & Partial R & $\begin{array}{c}\text { Semi- } \\
\text { Partial R }\end{array}$ & Tolerance & VIF \\
\hline Constant $^{b}$ & 1.629 & 0.998 & & 1.632 & 0.116 & & & & & \\
\hline Factor $2^{b}$ & 0.595 & 0.241 & 0.458 & 2.468 & 0.021 & 0.458 & 0.458 & 0.458 & 1.000 & 1.000 \\
\hline
\end{tabular}

Likewise, to try to generalize this explanatory model as a function of the men, the residues were studied, observing the non-multicollinearity with a VIF value $=1.000$ and the independence of the residues in the Durbin-Watson values $=1.953$. In addition, their linearity and the homoscedasticity of the residues observed in the graphics complied with these assumptions [41], just as their values of normality through the Kolmogorov-Smirnov test $(Z=0.076$ and $p=0.200)$.

In the meantime, for women, factor 2 explains $62 \%\left(R^{2}=0.620\right)$ of the general model of the development of mathematical thinking, where the parameters are $\mathrm{F}(1204)=335.923$ and $p<0.001$; factor 2, which is the only variable that intervenes in the equation, obtained the following statistics: $\mathrm{t}=18.328$ and $p<0.001$.

Table 11 shows the values that make up the equation that explains the development of mathematical thinking for women, which is factor1 $=0.55+0.82$ factor 2 .

Table 11. Linear regression of the development of mathematical thinking ${ }^{a, c}$ in early childhood education with the use of video games for women.

\begin{tabular}{|c|c|c|c|c|c|c|c|c|c|c|}
\hline Variables & B & E.S. & Beta & $\mathbf{t}$ & Sig. * & Zero Order & Partial R & $\begin{array}{c}\text { Semi- } \\
\text { Partial R }\end{array}$ & Tolerance & VIF \\
\hline Constant $^{b}$ & 0.548 & 0.182 & & 3.017 & 0.003 & & & & & \\
\hline Factor $2^{b}$ & 0.818 & 0.045 & 0.789 & 18.328 & 0.000 & 0.789 & 0.789 & 0.789 & 1.000 & 1.000 \\
\hline
\end{tabular}

Likewise, to try to generalize this explanatory model as a function of the women, the residues were studied, observing the non-multicollinearity with a VIF value $=1.000$ and the independence of the residues in the Durbin-Watson values $=2.066$. In addition, their linearity, and the homoscedasticity of the residues observed in the graphics complied with these assumptions [41], as do their values of normality through the Kolmogorov-Smirnov test $(Z=0.078$ and $p=0.200)$.

\section{Discussion}

The initiation of learning of mathematical contents in the early ages is an important matter for the education community, given that the establishment of prior knowledge in this area will allow the teacher to detect and determine future hurdles in the acquisition of concepts that will become more complex as the students make progress in the curricular content $[4,11]$.

On the other hand, the addition of the methodologies defined as active, based on the inclusion of diverse digital resources, will provide the teachers with a set of tools that will allow them to bring the social reality experienced by the students closer to the educational reality where they are immersed in during a considerable period of time in their lives [42,43]. However, the inclusion of a digital resource in the classroom methodology will be determined by the perception of the teachers [44]. Thus, knowing their opinion is of the utmost importance. In this sense, to discover their predisposition towards the addition of videogames to the curricular development of the subject of mathematics in the childhood education stage, the profile of the education professional must be understood. Our results showed that the participants in this study had a low level as videogame players, given that 
they spent a small amount of time playing videogames, as opposed to works by $[45,46]$, where the teachers-in-training spent a greater amount of time playing videogames and digital games.

Focusing our attention on the first objective of this work (Determine the perceptions of university students about the question of if the use of videogames makes possible the development of the curriculum in the early childhood stage in the area of mathematics), it can be verified that the teachers-in-training considered that the videogames would help students aged from 3 to 6 years old to understand and represent some logical and mathematical notions and relationships [47], which can be linked to their everyday lives [48].

On the other hand, they also considered that it would allow students aged from 3 to 6 years old to develop mathematical skill and knowledge [27] and reading comprehension and language, as opposed to the findings by [42], but in line with those found by [49]. In addition, in agreement with [50], the early childhood teachers-in-training believed that videogames would help children to acquire thinking schemes that will bring them closer to the basic notions of order, quantity, number series and functions [51], as well as problem-solving [52].

As for the second objective (To explore the existence of different dimensions about the use of videogames, to make progress feasible in the curriculum of the early childhood stage in the area of mathematics), the existence of two dimensions was corroborated, which brought together, on one hand, the items related to the skills linked with the comprehension of concepts where other curricular elements intervened, such as language, writing, and what was named "development of mathematical thinking" [52]. Moreover, a second dimension is linked to the "establishment of relationships between concepts" [27]. As for the grouping of the items into two dimensions, we verified that a line was followed as set by [6], given that this author also discusses experimentation and discovery on one hand and the relationships between concepts on the other.

With respect to the third objective of the work (To learn about the behavior of these factors, considering their relationships and the existence of an explanatory model for them), it was verified that the two-factor general explanatory model obtained pointed out that the women were closer to it than the men.

Lastly, focusing our attention to the starting hypothesis (There are significant differences in mathematical thinking depending on the establishment of relationships between concepts, without it being influenced by the age and gender of the study subjects), it is accepted and is also in line with the results obtained by [43].

In conclusion, gamification can increase both the cognitive load and the levels of performance, and generally, the students have positive beliefs with respect to the gamification strategies. This is a methodological strategy that allows creating work habits, fomenting participation and autonomy in problem-solving, promoting continuous learning, developing self-confidence and the ability to self-evaluate, promoting mathematical abilities and skills, and it could even motivate the Student's to perform activities that seemed boring to them before [11,12,25].

\section{Limits}

The field of Social Sciences has limitations in the development of research studies, which is related to the size of the sample. In relation to this, in the present study, a specific sample of teachers-in-training was utilized, which initially allowed us to validate the measurement instrument created, and whose results, although not able to be generalized, can serve as the basis of future research studies which utilize random samples of the population as the starting point. On the other hand, the data are unbalanced and have no element of randomization, so the results of the inferential study are very tenuous.

Author Contributions: Conceptualization, V.M.-D.; methodology, V.M.-D., J.M.M.-G. and B.E.S.-R.; validation, J.M.M.-G. and B.E.S.-R.; formal analysis, V.M.-D., J.M.M.-G. and B.E.S.-R.; investigation, V.M.-D. and N.N.J.-F.; resources, V.M.-D.; data curation, V.M.-D. and N.N.J.-F.; writing—original draft preparation, N.N.J.-F.; writing-review and editing, V.M.-D., B.E.S.-R.; project administration, V.M.-D., N.N.J.-F., J.M.M.-G. and B.E.S.-R.; funding acquisition, V.M.-D. All authors have read and agreed to the published version of the manuscript. 
Funding: This research received no external funding.

Conflicts of Interest: The authors declare no conflict of interest.

\section{Appendix A}

Table A1. General descriptive study.

\begin{tabular}{|c|c|c|c|c|}
\hline & M. & SD & Asymmetry & Kurtosis \\
\hline $\begin{array}{l}\text { and mathematical notions and relationships that refer to situations of } \\
\text { everyday life, coming closer to problem-solving strategies. }\end{array}$ & 3.57 & 0.937 & -0.7910 .160 & $0.179 \quad 0.318$ \\
\hline $\begin{array}{l}\text { Videogames will help with the use of spoken language in manners that are } \\
\text { more adequate to the different communication situations to understand } \\
\text { and be understood by others. }\end{array}$ & 2.97 & 1.077 & -0.1160 .160 & -0.9000 .318 \\
\hline $\begin{array}{l}\text { Videogames will help with coming closer to reading and writing in } \\
\text { situations of everyday life }\end{array}$ & 2.87 & 1.121 & $0.053 \quad 0.160$ & -1.0180 .3 \\
\hline $\begin{array}{l}\text { lp with the development of mathematical and logical } \\
\text { je }\end{array}$ & 3.71 & 0.868 & -0.9950 .160 & $1.278 \quad 0.318$ \\
\hline e, put into groups, & 3.72 & 0.890 & -0.8330 .160 & $0.615 \quad 0.318$ \\
\hline $\begin{array}{l}\text { Videogames will help with the acquisition of specific thinking schemes } \\
\text { that bring closer the basic mathematical notions of comparisons between } \\
\text { object collections }\end{array}$ & 3.72 & 0.859 & -0.8840 .160 & $0.911 \quad 0.3$ \\
\hline that bring closer the & 3.69 & 0.852 & -0.8400 .160 & $0.834 \quad 0.3$ \\
\hline $\begin{array}{l}\text { Videogames will help with the acquisition of specific } \\
\text { that bring closer the basic mathematical notions of qu}\end{array}$ & 3.69 & 0.878 & -1.0440 .160 & $1.160 \quad 0.318$ \\
\hline $\begin{array}{l}\text { Videogames } w \\
\text { that bring close }\end{array}$ & 3.73 & 0.815 & -1.0690 .160 & $1.285 \quad 0.3$ \\
\hline $\begin{array}{l}\text { Videogames will help with th } \\
\text { that bring closer the basic ma }\end{array}$ & 3.51 & 0.892 & -0.5240 .160 & -0.0390 .318 \\
\hline $\begin{array}{l}\text { Videogames } \mathrm{w} \\
\text { that bring close }\end{array}$ & 3.65 & 0.884 & -0.8070 .160 & $0.466 \quad 0.318$ \\
\hline $\begin{array}{l}\text { Videogames will help with learning how to use conventional or } \\
\text { unconventional mathematical codes as tools for expressing and } \\
\text { understanding qualitative and quantitative relationships that can be } \\
\text { established between objects and elements }\end{array}$ & 3.48 & 0.944 & -0.5720 .160 & $0.005 \quad 0.318$ \\
\hline $\begin{array}{l}\text { Videogames will help with using conventional or unconventional } \\
\text { mathematical codes as tools for expressing and understanding } \\
\text { qualitative and quantitative relationships that can be established } \\
\text { between objects and elements }\end{array}$ & 3.48 & 0.912 & -0.5890 .160 & $0.089 \quad 0.318$ \\
\hline $\begin{array}{l}\text { Videogames will help with establishing the relati } \\
\text { and the surrounding with quantifiable objects }\end{array}$ & 3.56 & 0.905 & -0.7610 .160 & $0.232 \quad 0.318$ \\
\hline $\begin{array}{l}\text { Videogames will help with establishing the relationships between the } \\
\text { different types of magnitudes }\end{array}$ & 3.51 & 0.892 & -0.5740 .160 & $0.142 \quad 0.318$ \\
\hline $\begin{array}{l}\text { Videogames will help with establishing the relationships between the } \\
\text { different types of matters }\end{array}$ & 3.50 & 0.926 & $-0.648 \quad 0.160$ & $0.023 \quad 0.318$ \\
\hline $\begin{array}{l}\text { Videogames will help with establishing the relationships between the } \\
\text { different types of sizes }\end{array}$ & 3.90 & 0.752 & -1.1270 .160 & $2.256 \quad 0.318$ \\
\hline Videogames will help with learning how to collect data and information & 3.95 & 0.818 & -0.8700 .160 & $0.897 \quad 0.318$ \\
\hline Videogames will help with learning how to represent data and informa & 3.68 & 0.894 & -0.5980 .160 & -0.0390 .318 \\
\hline
\end{tabular}




\section{References}

1. Sanz, N.; Alonso, A. La Escape Room educativa como propuesta de gamificación para el aprendizaje de la historia en Educación infantil. Didácticas Específicas 2020, 22, 7-25. [CrossRef]

2. Sampedro, B.E.; Muñoz, J.M.; Vega, E. El videojuego digital como mediador del aprendizaje en la etapa de Educación Infantil. Educar 2017, 53, 89-117. [CrossRef]

3. Cornellà, P.; Estebanell, M.; Brusi, D. Gamificación y aprendizaje basado en juegos. Enseñanza de las Ciencias de la Tierra 2020, 28, 5-19. Available online: https://www.raco.cat/index.php/ECT/article/view/372920 (accessed on 26 August 2020).

4. Marín, V.; Ramírez, A.; Sampedro Requena, B.E. Aprendemos a contar con los Lemmings. In Proceedings of the IV Congreso Internacional de Competencias Básicas: Tratamiento de la Información y Competencia Digital. Aprender en el Siglo XXI, Ciudad Real, Spain, 9-11 April 2014.

5. Novak, N.; Tassell, J. Using video game play to improve educationmajors' mathematical performance: An experimental study. Comput. Hum. Behav. 2015, 53, 124-130. [CrossRef]

6. Manzano-León, A.; Sánchez-Sánchez, M.; Trigueros-Ramos, R.; Álvarez-Hernández, J.; Aguilar-Parra, J.M. Gamificación y Breakout Edu en Formación Profesional. El programa «Grey Place» en Integración Social. EDMETIC 2020, 9, 1-20. [CrossRef]

7. Marín-Díaz, V. La Gamificación educativa. Una alternativa para la enseñanza creativa. Digit. Educ. Rev. 2015, $27,1-4$.

8. Yildirim, Y. The effects of gamification-based teaching practices on student achievement and students attitudes toward lessons. Internet High. Educ. 2017, 33, 86-92. [CrossRef]

9. Toda, A.M.; Valle, P.H.D.; Isotani, S. The Dark Side of Gamification: An Overview of Negative Effects of Gamification in Education. HEFA 2018, 832, 143-156. [CrossRef]

10. Serna-Rodrigo, R. Posibilidades de los videojuegos en el ámbito de la Didáctica de la Lengua y la Literatura. Una propuesta de clasificación. EDMETIC 2020, 9, 104-125. [CrossRef]

11. Maraza, B.; Alfaro, L.; Alejandro, O.; Cisneros Chávez, B.; Vica, R. Los videojuegos en el desarrollo de aprendizajes significativos en el área de Matemática. Rev. Ref. Pedagógica 2018, 6, 203-219.

12. Cantu, H.; Martínez-García, A.I. Videojuego serio sobre una superficie interactiva para fomentar la pre-lectoescritura en niños de 3 a 6 años dentro del aula. Revista de Tecnologías Emergentes en la Educación 2016, 1, 76-81.

13. Holguin, J.; Taxa, F.; Flores, R.; Olaya, S. Proyectos educativos de gamificación por videojuegos: Desarrollo del pensamiento numérico y razonamiento escolar en contextos vulnerables. EDMETIC 2020, 9, 80-103. [CrossRef]

14. Sánchez-Rivas, E.; Ruíz-Palmero, J.; Sánchez-Rodríguez, J. Videojuegos frente a fichas impresas en la intervención didáctica con alumnado con necesidades educativas especiales. Educar 2017, 53, 29-48. [CrossRef]

15. Alsina, À.; Heredia, I. Enriquecimiento curricular de alumnos con talento matemático: Un estudio de caso con apoyo de nuevas tecnologías. Mat. Educ. Soc. 2018, 1, 15-30.

16. Yung, O.C.; Junaini, S.N.; Kamal, A.; Ibharim, L.F. 1 Slash 100\%: Gamification of mathematics with hybrid QR-based card game. Indones. J. Electr. Eng. Comput. Sci. 2020, 20, 1453-1459. [CrossRef]

17. Fokides, E. Digital educational games and mathematics. Results of a case study in primary school settings. Educ. Inf. Technol. 2018, 23, 851-867. [CrossRef]

18. Udjaja, Y.; Guizot, V.S.; Chandra, N. Gamification for Elementary Mathematics Learning in Indonesia. Int. J. Electr. Comput. Eng. 2018, 8, 3859-3865. [CrossRef]

19. Cope, L. Math Manipulatives: Making the Abstract Tangible. Delta J. Educ. 2015, 5, 10-19.

20. Ball, D.L. Magical hopes: Manipulatives and the reform of math education. Am. Educ. Prof. J. Am. Fed. Teach. 1992, 16, 14-47.

21. Hieftje, K.; Pendergrass, T.; Kyriakides, T.C.; Gilliam, W.; Fiellin, L. An evaluation of an educational video game on mathematics achievement in first grade students. Technologies 2017, 5, 30. [CrossRef]

22. Romero, A.; Espinosa, J. Gamificación en el aula de educación infantil: Un proyecto para aumentar la seguridad en el alumnado a través de la superación de retos. Edetania Estud. Propues. Socioeduc. 2020, 56, 61-82. [CrossRef] 
23. Lamrani, R.; Abdelwahed, E.H.; Chraibi, S.; Qassimi, S.; Hafidi, M. Gamification and Serious Games Based Learning for Early Childhood in Rural Areas. In Communications in Computer and Information Science; Springer: Berlin/Heidelberg, Germany, 2018; Volume 929. [CrossRef]

24. Fernández-Oliveras, A.; Molina-Correa, V.; Oliveras, M.L. Estudio de una propuesta lúdica para la educación científica y matemática globalizada en infantil. Revista Eureka sobre Enseñanza y Divulgación de las Ciencias 2016, 13, 373-383. Available online: http://hdl.handle.net/10498/18294 (accessed on 5 August 2020). [CrossRef]

25. Mowafi, Y.; Abumuhfouz, I.; Redifer, J. A Play-Based Interactive Learning Approach for Fostering Counting and Numbers Learning Skills for Early Childhood Education Using QR Codes Mobile Technologies. In Mobile Web and Intelligent Information Systems; Lecture Notes in Computer Science; Awan, I., Younas, M., Ünal, P., Aleksy, M., Eds.; Springer: Cham, Switzerland, 2019; Volume 11673, pp. 16-26. [CrossRef]

26. Salsabila, N.H.; Hapipi, H.; Lu'luilmaknun, U. Students' Perceptions Towards Educational Games Learning Media in Mathematics. Adv. Soc. Sci. Educ. Humanit. Res. 2020, 465, 127-131. [CrossRef]

27. Machaba, M. Mathematical games as tool for mathematics teaching in the foundation phase. e-Bangi 2019, 16, 1-8. Available online: http://ejournal.ukm.my/ebangi/article/view/33422 (accessed on 12 September 2020).

28. Rahayu, C.; Putri, R.I.I.; Hartono, Y. Using mathematics education game based ICT: Why children like to play game? J. Phys. Conf. Ser. 2019, 1315, 012062. [CrossRef]

29. Otzen, T.; Manterola, C. Técnicas de muestreo sobre una población a estudio. Int. J. Morphol. 2017, 35, $227-232$. [CrossRef]

30. Morales, P. Tamaño Necesario de la Muestra: ¿Cuántos Sujetos Necesitamos? 2012. Available online: http://www.upcomillas.es/personal/peter/investigacion/Tama\%F1omuestra.pdf (accessed on 12 September 2020).

31. Gialamas, V.; Nikolopouiou, K.; Kutromanos, G. Student teachers? perceptions about the impact of Internet usage on their learning and jobs. Comput. Educ. 2013, 62, 1-7. [CrossRef]

32. Sampedro, B.E.; Marín-Díaz, V.; Vega, E. El Valor de Internet Según los Jóvenes Universitarios. Estudio de Caso. Universitas Tarraconensis 2016, 2, 39-51. [CrossRef]

33. Real Decreto 1630/2006, de 29 de Diciembre, Por el Que se Establecen las Enseñanzas Mínimas del Segundo Ciclo de Educación Infantil. Boletín oficial del Estado 2006, 4, 474-482.

34. Orden de 5 de Agosto de 2008, Por la Que se Desarrolla el Currículo Correspondiente a la Educación Infantil en Andalucía. Available online: https://www.juntadeandalucia.es/boja/2008/169/3 (accessed on 12 September 2020).

35. Timmerman, M.E.; Lorenzo-Seva, U. Dimensionality Assessment of Ordered Polytomous Items with Parallel Analysis. Psychol. Methods 2011, 16, 209-220. [CrossRef]

36. Lorenzo-Seva, U. The weighted oblimin rotation. Psychometrika 2000, 65, 301-318. [CrossRef]

37. Byrne, B.M. Factor Analytic Models: Viewing the Structure of an Assessment Instrument from Three Perspectives. J. Personal. Assess. 2005, 85, 17-32. [CrossRef] [PubMed]

38. Arias, B. Desarrollo de un ejemplo de análisis factorial confirmatorio con LISREL, AMOS y SAS. In Metodología en la Investigación Sobre Discapacidad; En, M.A., Verdugo, M., Crespo, M., Badía, Y., Arias, B., Eds.; INICO: Salamanca, Spain, 2008; pp. 75-120.

39. Mateo, J. La investigación ex post-Facto. In Metodología de la Investigación Educativa, 3rd ed.; Bisquerra, R., Coord, Eds.; La Muralla: Madrid, Spain, 2012; pp. 195-229.

40. Gil, J.A. Metodología Cuantitativa en Educación; UNED: Madrid, Spain, 2015.

41. Hancock, G.R.; Stapleton, L.M.; Mueller, R.O. The Reviewer's Guide to Quantitative Methods in the Social Sciences, 2nd ed.; Routledge: New York, NY, USA, 2019.

42. Brazo, A.I.; Muñoz, J.M.; Castro, C. Aprendiendo léxico y ortografía francesa en la universidad mediante el videojuego SRIBBLENAUTS. EDMETIC 2018, 7, 18-36. [CrossRef]

43. Aguilar, J.J.; Telese, J.A. Perceptions and Opinions of the Usability of Simulations in a Mathematics Methods Course for Elementary Pre-Service Teachers. J. Educ. Pract. 2020, 11, 9-14.

44. Gallardo, I.M.; San Nicolas, M.B.; Coret, A. Visiones del profesorado de primaria sobre materiales didácticos digitales. Campus Virtuales 2019, 8, 47-62.

45. Marin-Díaz, V.; Moreno, M.; Reche-Urbano, E. Educational possibilities of video games in the Primary Education stage according to teachers in training. NAER 2019, 8, 42-49. [CrossRef]

46. Korkmaz, U.; Avci, Z.Y. Turkish Pre-Service Teachers' Experiences with Contemporary Technology Games and Perceptions About Teaching with Instructional Games. Res. Soc. Sci. Technol. 2016, 1. Available online: https://www.learntechlib.org/p/187549/ (accessed on 25 August 2020). 
47. Chao, T.; Chen, J.; Star, J.R.; Dede, C. Using Digital Resources for Motivation and Engagement in Learning Mathematics: Reflections from Teachers and Students. Digit. Exp. Math. Educ. 2016, 2, 253-277. [CrossRef]

48. Zaranis, N.; Kalogiannakis, M.; Papadakis, S. Using mobile devices for teaching realistic mathematics in kindergarten education. Creat. Educ. 2013, 4, 1. Available online: https://www.scirp.org/html/34168.html (accessed on 25 August 2020). [CrossRef]

49. Toussaint, M.J.; Brown, V. Connecting the arcs motivational model to game design for mathematics learning. Transformations 2018, 4, 19-28. Available online: https://nsuworks.nova.edu/cgi/viewcontent.cgi?article= 1018\&context=transformations (accessed on 25 August 2020).

50. Morales, M. Viabilidad del uso del videojuego en el aula: Opiniones prácticas de los maestros en pre-servicio. EDMETIC 2018, 7, 78-91. [CrossRef]

51. Beltrán-Pellicer, P. Una propuesta sobre probabilidad en educación infantil con juegos de mesa. Edma 0-6 Educación Matemática en la Infancia 2017, 6, 53-61. Available online: http://www.edma0-6.es/index.php/edma0-6/article/ view/25 (accessed on 10 September 2020).

52. Yong, S.T.; Gates, P.; Chan, A.T.Y. Similarities and Differences in Learning of Metacognitive Skills: Computer Games Versus Mathematics Education. Int. J. Game-Based Learn. 2019, 9, 1-14. [CrossRef]

Publisher's Note: MDPI stays neutral with regard to jurisdictional claims in published maps and institutional affiliations.

(C) 2020 by the authors. Licensee MDPI, Basel, Switzerland. This article is an open access article distributed under the terms and conditions of the Creative Commons Attribution (CC BY) license (http://creativecommons.org/licenses/by/4.0/). 